\title{
Fisheries Biology of the twobar Seabream, Acanthopagrus bifasciatus from the Egyptian Sector of the Red Sea
}

\author{
Azza A El Ganainy, Hanan M Osman*, Amgad M Shaaban and Mahmoud A Saber \\ National Institute of Oceanography and Fisheries, Egypt
}

Submission: January 26, 2021; Published: March 17, 2021

Corresponding author: Hanan Mohamed Osman, National Institute of Oceanography and Fisheries, Egypt

Abstract

The growth and reproductive biology of the commercially important reef fish, the twobar seabream, Acanthopagrus bifasciatus, were investigated in order to evaluate the impact of fishing on its resource, and to derive information required for its management in the Red Sea. Samples were collected during 2017-2019 from Hurgada fishing harbor. Age was determined by using sagittal otolith. The maximum age recorded was 18 years. The von Bertalanffy growth parameters fit to length at age data were estimated as $\mathrm{K}=0.131$ year-1, $\mathrm{L}_{\infty}=59.48 \mathrm{~cm}$ $(\mathrm{TL}), \mathrm{t}_{\mathrm{o}}=-1.778$ years. The length-weight relationship for combined sexes was represented by the equation, $\mathrm{W}=0.0135^{*} \mathrm{~L}^{3.1112}$ which exhibit positive allometric growth. Spawning was recorded during January and February, and the mean sizes and ages at first sexual maturity were 27.2 $\mathrm{cm}$ (2.9 years) for males and $30.1 \mathrm{~cm}$ (3.6 years) for females. Sex ratio was (females $50.5 \%$, males $48.4 \%$ and hermaphrodites $1.1 \%$ ). Sex ratio by size indicated that females were dominant among small/young fishes while males were dominant among old/large fishes. This suggested a protogynous hermaphrodite life history style, which may be widespread in Acanthopagrus species. The rate of fishing mortality $\left(\mathrm{F}_{\text {cur }}=0.238\right)$ exceeded the target $\left(\mathrm{F}_{\mathrm{opt}}=0.121\right)$, and the limit reference points $\left(\mathrm{F}_{\text {limit }}=0.161\right)$. Further expansion of the fishery should be constrained.

Keywords: Age and growth; Mortalities; Reproduction; Acanthopagrus bifasciatus; Red Sea

\section{Introduction}

Family sparidae (known as seabreams or porgies) are rocky fishes occur in shallow coastal waters; enter estuaries and bays, mainly around coral reefs [1]. Many sparids have hermaphroditism, when reaching sexual maturity, the majority of individuals could be males (protandric hermaphroditism) or females (protogynic hermaphroditism) [2]. Most of these fishes are carnivorous, feeding principally on mollusks or crustaceans. Twelve species of Sparid fishes were reported from the Red Sea [3]. Because of their good quality meat, many species of this family have a high commercial value.

Twobar seabream, Acanthopagrus bifasciatus (Forsskål, 1775) is a sparid fish inhabits outer reef flats, deep lagoons, bays, and seaward reefs, two-to-twenty-meter depth. It prefers reef flats with deep holes and reef margins often in wave areas. It tends to be solitary or in small semi-stationary groups near shelter. The twobar seabream is distributed in the Red Sea and the Arabian Gulf as well as South Africa and Mauritius [4]. Large individuals of the twobar Seabream are fished in the Red Sea by hooks and line, while small individuals are caught by gill nets. Juveniles and adults of twobar seabream mainly feed on zoobenthos, mollusks, worms, and benthic crustaceans [5]. Although, this fish is very important to the local recreational and commercial fishery in the Red Sea, its annual catch is not known due to including its landings in the unsorted catch category [6].

The population biology and fishery status of the twobar Seabream, A. bifasciatus were studied by some authors in the Arabian Gulf and in the Gulf of Aden [5,7-10]. This study aims to estimate the demographic characteristics of the long-lived reef fish species A. bifasciatus and the effects of fishing on its population as well as some Biological parameters including estimation of growth and mortality rates based on otolith readings, biological reference points and some aspects of the reproductive biology in the Red Sea which provide information necessary for its stock management. 


\section{Materials and Methods}

Random samples of A. bifasciatus were collected from commercial catches in the different landing sites off the Egyptian Red Sea coast (Figure 1) during 2017- 2019. A total of 196 fish of a representative size range were used in this study. Total length in $\mathrm{cm}$, total weight in $\mathrm{g}$ and sex were recorded for each specimen. The otoliths were removed, cleaned, and kept in special envelopes for later age determination by using the stereo microscopes at a magnification of $40 \mathrm{X}$. Size-at-age data were fitted to the von Bertalanffy growth function non- linear least squares technique the mean square error was used as an index of goodness of fit. The model was fitted to pooled data $[11,12]$. The length-weight relationship parameters were obtained by applying the power function $\mathrm{W}=\mathrm{aL}^{\mathrm{b}}$, as $\mathrm{W}$ is the total weight, $\mathrm{L}$ is the total length and $\mathrm{a}$, and $\mathrm{b}$ are constants determined empirically.

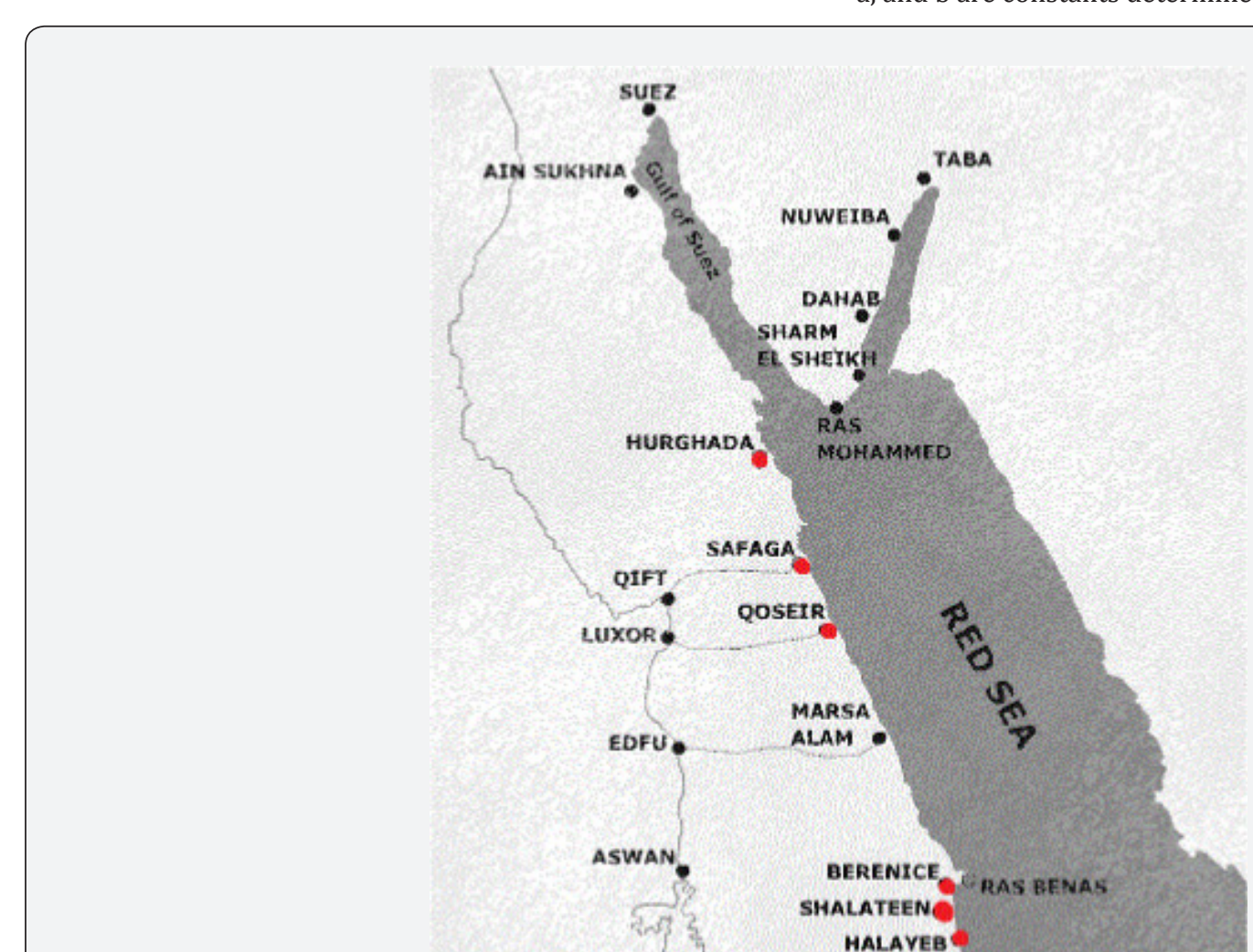

Figure 1: Map of the landing sites (red circles) in the Red Sea.

The size at first sexual maturity $\left(\mathrm{L}_{\mathrm{m}}\right)$ was estimated for both sexes by fitting the logistic function to the proportion of mature fish in 5-cm (L) size categories. The size at first sexual maturity was taken as the size at which $50 \%$ of individuals were mature. Timing of spawning was determined using the average monthly gonado-somatic indices (GSI). GSI indices were calculated for each sex by expressing the gonad weight as a proportion of total body weight. The rate of total mortality (Z) was determined by applying the age-based catch curve method of the instantaneous rate of natural mortality $(\mathrm{M})$ was estimated using model updated by as $\mathrm{M}$ $=4.118 \mathrm{~K}^{0.73} \mathrm{~L}_{\infty}^{-0.33}$ where $\mathrm{K}$ and $\mathrm{L}_{\infty}$ are the von Bertalanffy growth parameters [13-15].

The fishing mortality (F) was calculated by subtracting the natural mortality rate $(\mathrm{M})$ from the total mortality rate $(\mathrm{Z})$. The rate of exploitation (E) was calculated by the equation $(E=F / Z)$. Precautionary target biological reference points, optimum fishing mortality $\left(F_{\text {opt }}\right)$ and Limit fishing mortality $\left(F_{\text {lim }}\right)$ were calculated as $1 / 2 \mathrm{M}$ and $2 / 3 \mathrm{M}$, respectively according to and were compared with the estimated fishing mortality [16]. The length at first capture $\left(L_{c}\right)$, the length at which $50 \%$ of the catch retained in the net, was obtained according to [17]. The size that generates maximum yield per recruit was estimated by the empirical equations according to [18].

\section{Results}

\section{Age and Growth}

Total length measurements ranged from $20.7 \mathrm{~cm}$ to $55.3 \mathrm{~cm}$ with an average of $37.30 \pm 7.66 \mathrm{~cm}$ (Figure 2) while the total weight measurements varied from 169 to $3868 \mathrm{~g}$. with an average of $1219.65 \pm 793.44 \mathrm{~g}$. The length-weight relationship (Figure 3) was calculated to be $\mathrm{W}=0.0135^{*} \mathrm{~L}^{3.1112}$ (ANOVA, $F=4374.5, P$ $<0.01)$ by: $\left(r^{2}=0.979, \mathrm{SE}_{\mathrm{a}}=0.169, \mathrm{SE}_{\mathrm{b}}=0.047\right)$. The growth of weight relative to length was positive allometric ( $b=3.1112 ; 95 \%$ CI: 3.018-3.205) as the obtained isometric index value $(b)$ was significantly different from 3 (Student's $t$-test; $P<0.05$ ). 


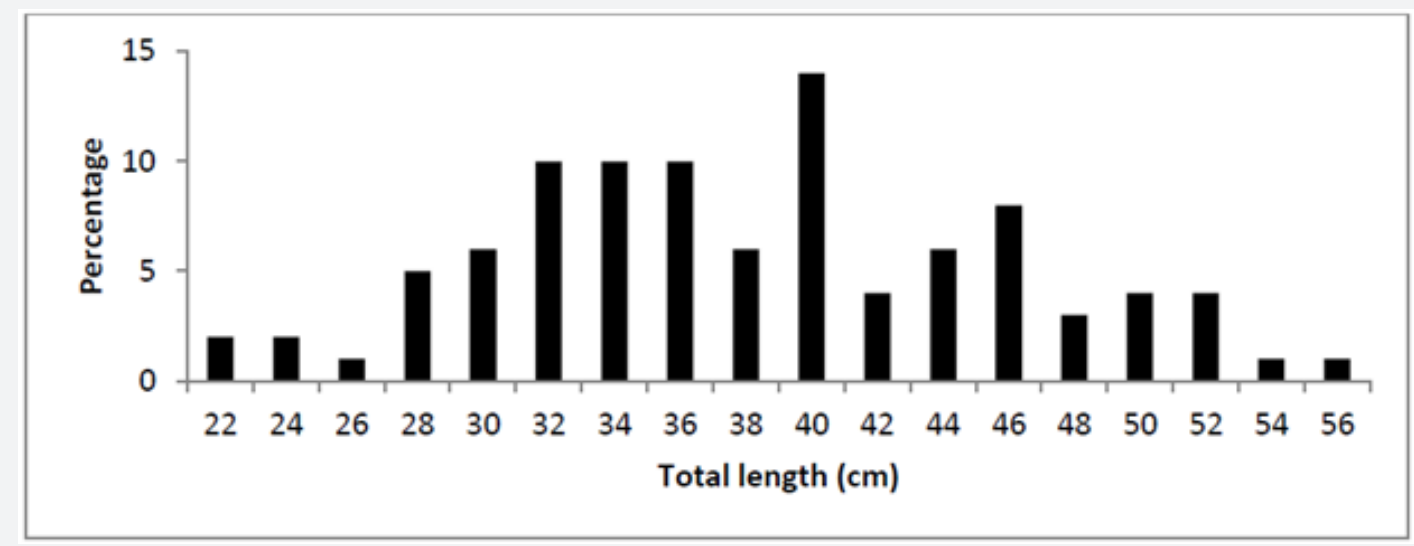

Figure 2: Length frequency distribution of $A$. bifasciatus from the Red Sea.

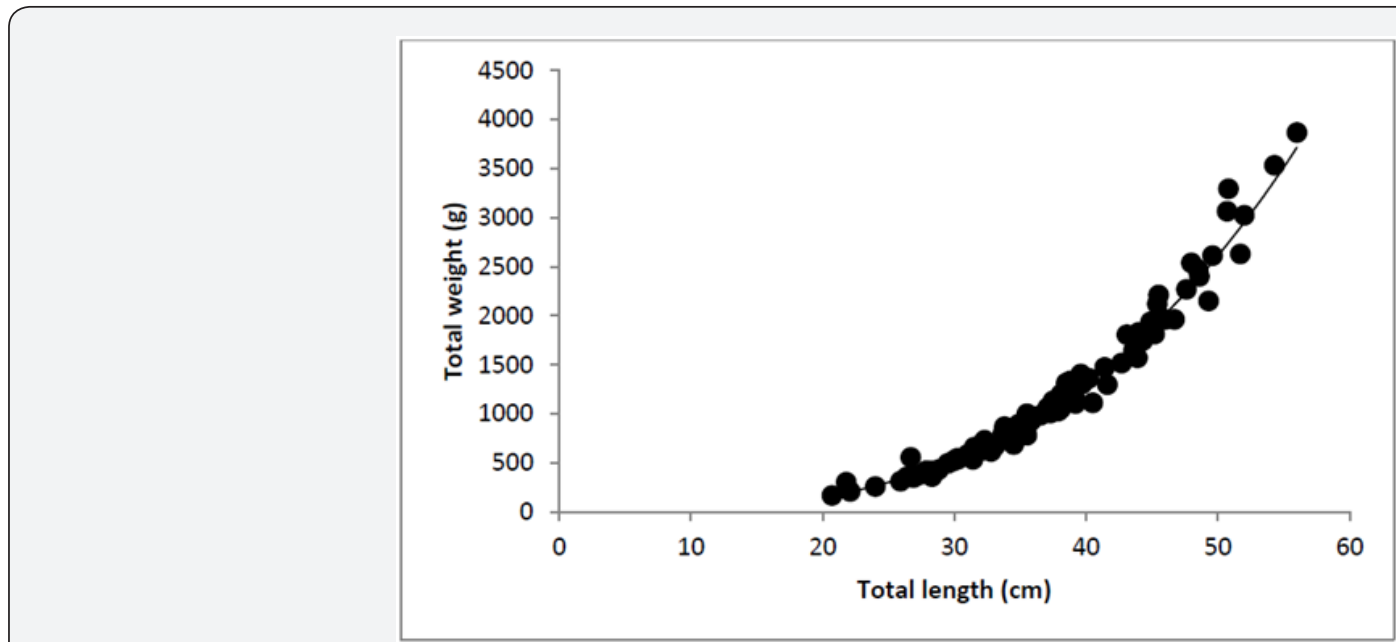

Figure 3: Length weight relationship of $A$. bifasciatus from the Red Sea.

The otoliths of 196 fishes were used for age determination. Alternating translucent and opaque zones were clearly observed in the otoliths of $A$. bifasciatus, an opaque and translucent zone constituting one growth ring that formed annually. The validity of the annulus as a true year mark was tested by: (1) The relationship between the total fish length and number of rings showed a good correlation coefficient $\left(r^{2}=0.896\right)$, and (2) The close agreement between the observed and calculated lengths at age $(P=0.00013)$.

The maximum estimated age from otolith reading was 18 years. Age group one was not represented in the sample. The size-at-age relationships were asymptotic, the highest growth rate occurs in the second and third year, and then in the following years the growth rate slows down. The mean lengths at age for all aged specimens were used for fitting the growth curve (Figure 4) and determination of the VBGF parameters. The resulting VBGF parameters were $\mathrm{L}_{\infty}=59.48 \mathrm{~cm}(\mathrm{SE}=1.80$ and C.V. $=0.037), \mathrm{K}=$ 0.131 year $^{-1}(\mathrm{SE}=0.038$ and C.V. $=0.169)$ and $\mathrm{t}_{\mathrm{o}}=-1.778(\mathrm{SE}=$ $0.256)$.

\section{Reproduction}

Sex was determined for 188 fish, from these 95 (50.5\%) were females, 91 (48.4\%) were males and 2 (1.1\%) were hermaphrodites. Sex ratio by size indicated that females were dominant among small/young fish $(<26.0 \mathrm{~cm})$ while males were dominant among old/large fish $(>50 \mathrm{~cm}$ ) (Figure 5). Monthly average of the gonado- somatic index (GSI) values of females and males are given in Figure 6. In both sexes, gonads start to mature in December. The maximum average GSI value was reported in February for females (4.03) and for males (1.98). It was observed that reproduction begins in January and continued until April with a peak in February.

The length at which $50 \%$ of individuals attained sexual maturity was estimated to be $27.2 \mathrm{~cm}$ TL for males and $30.1 \mathrm{~cm}$ TL for females (Figure 7). There was considerably more variation among samples for length at maturity for males than for females. The corresponding estimated age at which $50 \%$ of individuals 
attained sexual maturity was 2.9 years for males and 3.6 years for females. The smallest observed mature male and female was 22.1 and $25.5 \mathrm{~cm}$, respectively.

\section{Mortalities and Biological Reference Points}

The instantaneous rate of total mortality (Z) derived from the age-based catch curve (Figure 8) was 0.48 (0.39-63, 95\% CI). The instantaneous rate of natural mortality (M) was estimated at 0.242 . The instantaneous rate of fishing mortality (F) was 0.238 $(0.15-0.39,95 \% \mathrm{CI})$, and the exploitation rate (E) was 0.496
The mean size at first capture $\left(\mathrm{L}_{50}\right)$ was $34.3 \mathrm{~cm}$, and the size at capture at a probability of $0.75\left(\mathrm{~L}_{75}\right)$ was $38.9 \mathrm{~cm}$ (Figure 9). Fish were fully recruited at a size $\left(\mathrm{L}_{100}=40.0 \mathrm{~cm}\right)$ corresponding to an age of 9 years. The calculated length that generates the maximum possible yield $\left(\mathrm{L}_{\text {opt }}\right.$ ) was $36.2 \mathrm{~cm}$ (s.e. of 33.0- 39.7); this value is greater than the mean size at first capture $\left(\mathrm{L}_{\mathrm{c}}=34.3 \mathrm{~cm}\right)$ and the mean size at first sexual maturity $\mathrm{L}_{\mathrm{m}}=28.65 \mathrm{~cm}$ (Figure 10). The estimated instantaneous rate of fishing mortality $\left(\mathrm{F}_{\text {cur }}=0.238\right)$ is higher than the target $\left(\mathrm{F}_{\mathrm{opt}}=0.121\right)$ and the limit reference points $\left(\mathrm{F}_{\text {limit }}=0.161\right)$.

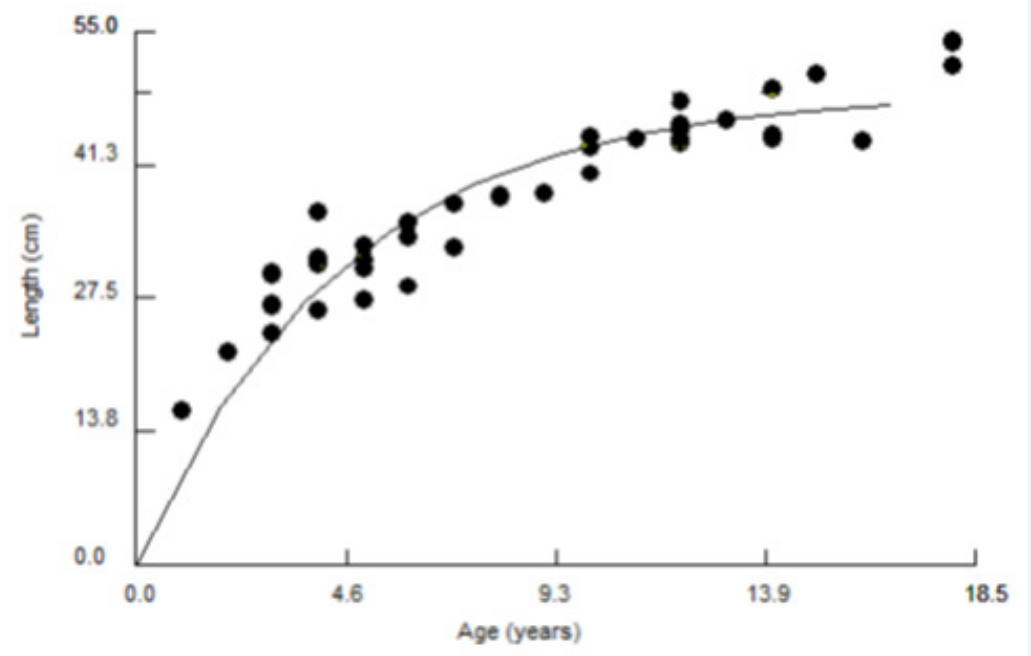

Figure 4: Length at age of A. bifasciatus from the Red Sea.

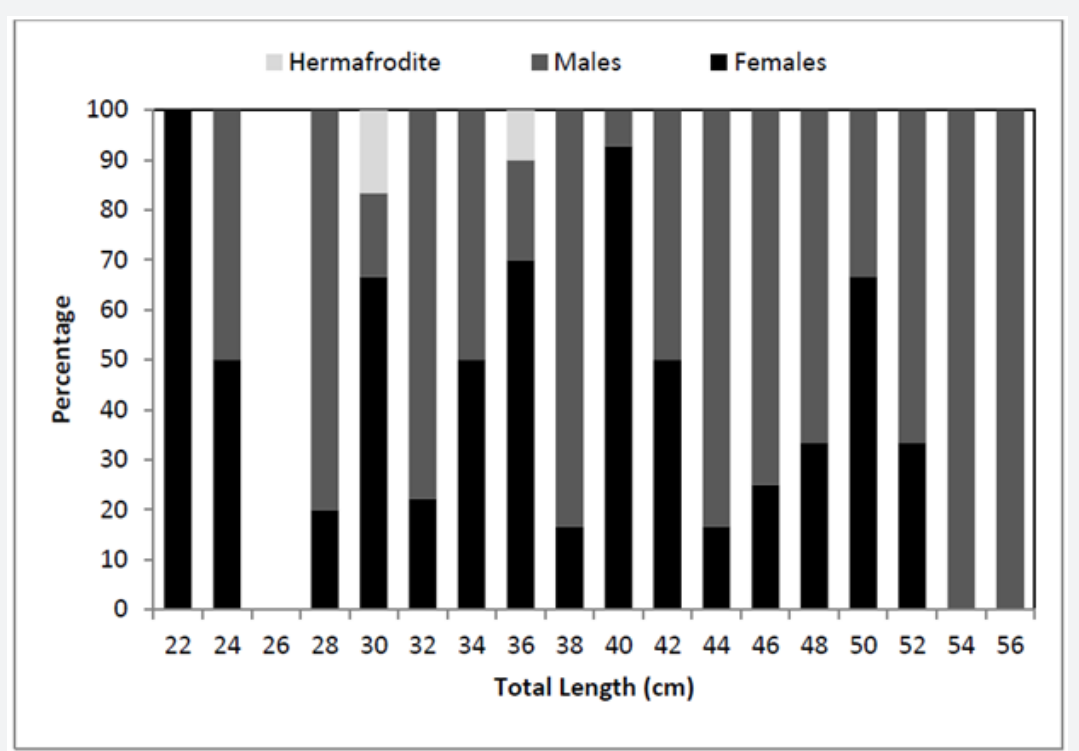

Figure 5: Location of Boleophthalmus pectinirostris records in Sumatra. Black stars show the previous record from Tebing Tinggi and Bengkalis Island, Riau Province; and black triangles show records during 2006-2017 in South Sumatra Province and Bangka island, Sumatra, Indonesia. 


\section{Oceanography \& Fisheries Open access Journal}

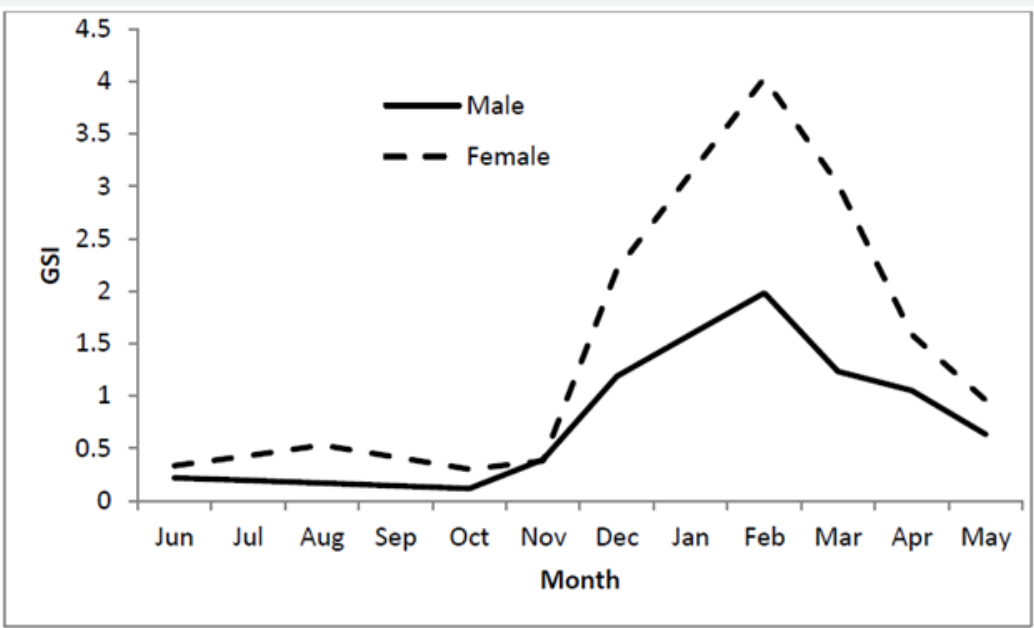

Figure 6: Monthly variations in gonadosomatic index of $A$. bifasciatus from the Red Sea.

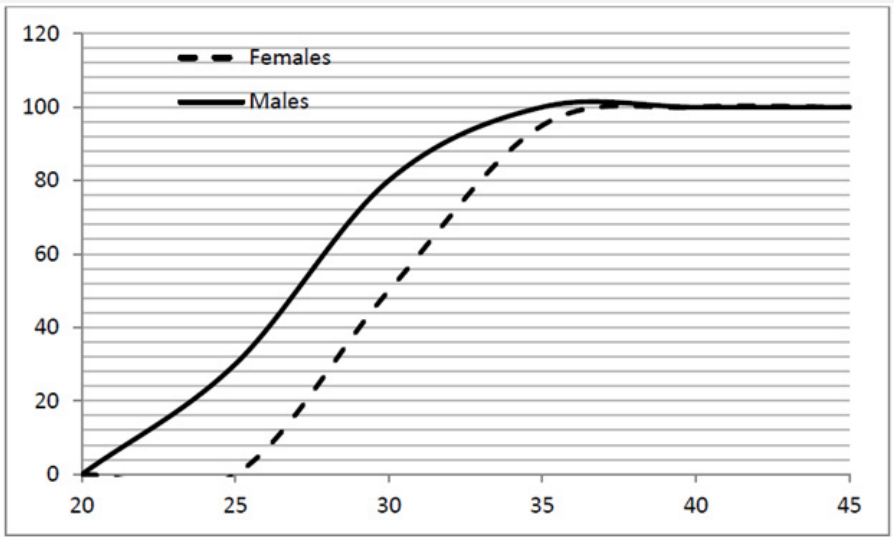

Figure 7: Length at first maturity of male and female A. bifasciatus from the Red Sea.

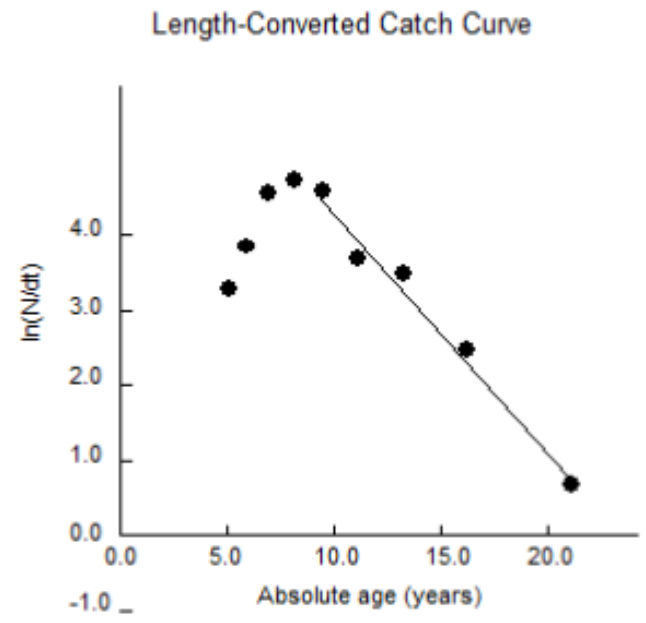

Figure 8: Age based catch curve of $A$. bifasciatus from the Red Sea. 


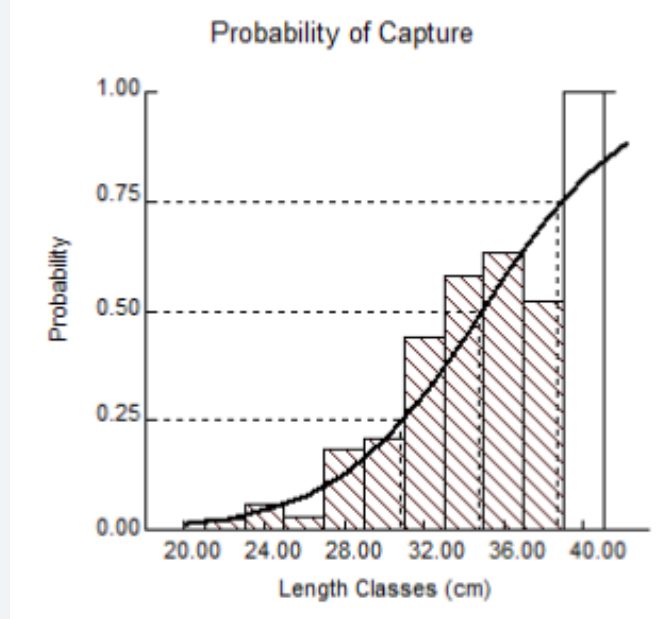

Figure 9: Probability of capture of $A$. bifasciatus from the Red Sea.

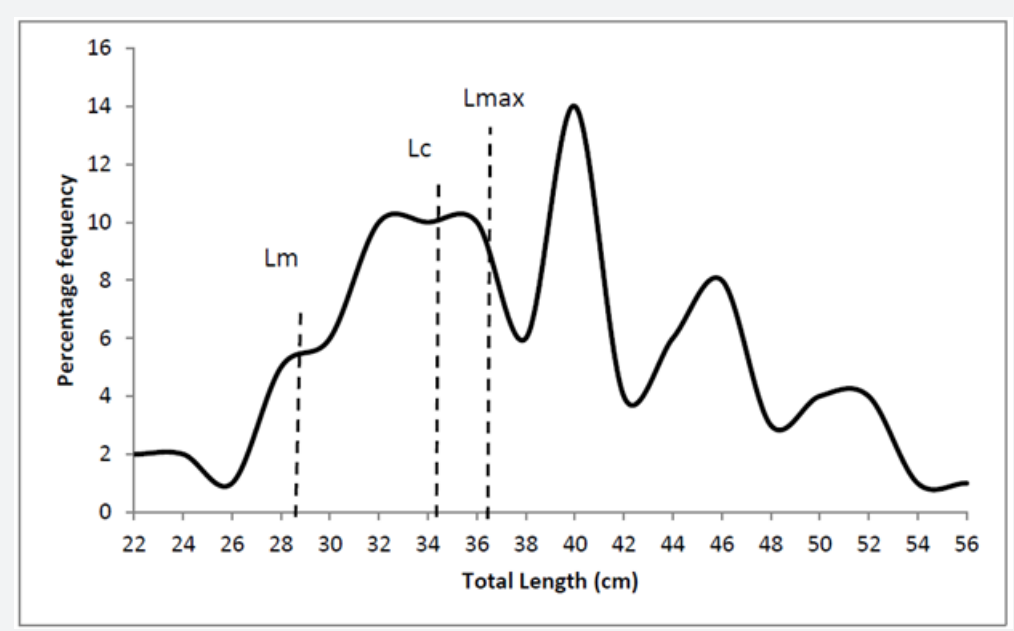

Figure 10: Length frequency distribution showing the mean lengths at first maturity $\left(L_{m}\right)$, first capture $\left(L_{c}\right)$ and minimum yield per recruit $\left(L_{\max }\right)$ for A. bifasciatus from the Red Sea.

\section{Discussion}

Seabreams support an important commercial fishery in the Red Sea. The twobar seabream A. bifasciatus is a common seabream species of an economic importance to recreational and commercial fisheries. It represents an important source of protein in the Egyptian Red Sea. This study throws light on some population parameters and biological characteristics of this valuable species caught by artisanal fishery in the Red Sea. The length frequency distribution of the 196 specimens collected in the current study showed that the dominant length group of the catch was $38.0-40.0 \mathrm{~cm}$ (14.4\% of the total sample size). The recorded fork length range of 18.7-41.7 $\mathrm{cm}$ for samples collected during trawling survey in the Gulf of Aden [10]. Pointed out that the dominant length group in the catch of $A$. bifasciatus from Arabian Gulf is $28.0-28.9 \mathrm{~cm}$. The length-weight relationship indicated a positive allometric growth in accordance with the findings of [5]. In other studies, in the Arabian Gulf the growth was isometric while reported that the growth is negative allometric in the Gulf of Aden [7-10].

A large number of methods are available for fish age determination; however, the use of the whole otoliths immersed in Alcohol and glycerol solution proved to give adequate results for the twobar seabream A. bifasciatus. Otoliths reading showed 18 age groups, one annulus was formed per year. This result was comparable to the maximum age of 19 and 21.3 years estimated by and for the species in the Arabian Gulf [7,9]. While a maximum age of 10 and 9 years was reported by for A. bifasciatus in the Gulf of Aden and by in Arabian Gulf, respectively $[5,10]$. As most of the sparid fishes, A. bifasciatus is characterized by long lifespan and slow rate of growth $[7,19]$. The long lifespan was recorded for 
a number of Achanthopagrus species (i.e., 24 for A. latus; 17 for A. berda; up to 21 for A. butcheri; 29 and 31 for Acanthopagrus hybrid complexes; 28 for $A$. schlegelii) [19,20-22].

The estimated growth rate $(\mathrm{K}=0.131)$ agrees with the previous studies [7-10], while it is lower than that $(K=0.198)$ estimated by [5]. The asymptotic maximum size $\left(\mathrm{L}_{\infty}\right)$ is correspondingly the highest (Table 1). It seems that there is a great contradict in the growth pattern estimated by the different authors and even in works in the same geographical area [23]. The difference in environmental conditions and ecosystem characteristics in the different areas may explain the amount of variation in the estimates. In most of these cases the differences in growth parameters may be attributed to the ageing methodology, range of size and sample sizes used.

Table 1: Estimated growth parameters for Achanthopagrus bifasciatus in different areas.

\begin{tabular}{|c|c|c|c|c|c|c|}
\hline Age & $\mathbf{L}_{\infty}$ & $\mathbf{K}$ & $\mathbf{t}_{\mathbf{o}}$ & Method & Author \\
\hline $1-10$ & 49.8 & 0.25 & -0.035 & Vertebrae & Gulf of Aden \\
\hline $1-19$ & 34.9 & 0.19 & -2.24 & Scales & Arabian Gulf (Kuwait) \\
\hline $1-14$ & 47.12 & 0.14 & -1.69 & Scales & Arabian Gulf (Qatar) \\
\hline $1-21$ & 32.5 & 0.234 & -2.2 & Otoliths & Southern Arabian Gulf \\
\hline $1-10$ & 53.5 & 0.198 & -1.083 & Scales & Arabian Gulf (Abu Dhabi) & [9] \\
\hline $2-18$ & 59.48 & 0.131 & -1.778 & Otoliths & Egyptian Red Sea \\
\hline
\end{tabular}

Analysis of sex ratios and size structure of the twobar seabream showed that females were dominant among small/ young fish while males were dominant among old/large fish, this life history might be considered a protogynous hermaphroditism. These findings agree with [9]. In contrast, reported that $A$. bifasciatus is a protandrous hermaphrodite. The spawning period estimated in the current study, that extending from January to April with a peak in February, is identical to that reported and for A. bifasciatus in the Arabian Gulf [24].

The results showed that male and female A. bifasciatus were fully recruited to the fishery in the Red Sea at a size larger than the size at first sexual maturity and the juvenile retention rate (proportion of fish below the size at first sexual maturity) for females was $15.9 \%$ while that of males was $10.9 \%$. This indicates that the twobar seabream is exploited in the Egyptian Red Sea in a sustainable level. However, the estimated fishing mortality rate $\left(F_{\text {cur }}=0.238\right)$ exceeded the target, and the limit reference points. So, further expansion of the fishery should be constrained. Also, the size at which fish fully recruited to the fishery $(40.0 \mathrm{~cm})$ is higher than the size at which yield per recruit would be maximized $(36.2 \mathrm{~cm})$, so there is a require for some management regulations for adjusting the selectivity characteristics of fishing gears.

\section{References}

1. Froese R, Pauly D (2019) Fish Base. World Wide Web electronic publication.

2. Moretti A, Fernandez-Criado MP, Cittolin G, Guidastri R (1999) Manual on Hatchery Production of Seabass and Gilthead Seabream. Rome FAO 1: 194.

3. Randall J (1983) Red Sea reef fishes. Immel Publication 182.

4. Lieske E, Myers RF (2004) Coral reef guide Red Sea. Collins publications.
5. Taher MM (2010) Biological aspects of twobar seabream Acanthopagrus bifasciatus (Forsskål, 1775) in water surrounding Sammaliah island Abu Dhabi. Basrah Journal of Agriculture Sciences 23: 1-15.

6. El-Ganainy AA (2017) Stock assessment and gear description of the Red Sea and Gulf of Suez fisheries for their proper management. Science and Technology development Fund (STDF), Egypt 124.

7. Samuel M, Mathews CP (1987) Growth and mortality of four Acanthopagrus species. Kuwait Bulletin of Marine Science 9: 159-171.

8. El-Sayed AM, Abdel-Bary K (1993) Population biology of sparid fishes in Qatari waters 2 Age, growth and mortality of black-banded bream, Mylio bifasciatus (Forsskal). Qatar University Science Journal 13: 348352 .

9. Grandcourt EM, Al Abdessalaam TZ, Francis F, Al Shamsi AT (2004) Biology and stock assessment of the sparids, Acanthopagrus bifasciatus and Argyrops spinifer (Forsskål, 1775), in the Southern Arabian Gulf. Fisheries Research 69: 7-20.

10. Edwards RRC, Bakhader A, Shaher S (1985) Growth, mortality, age composition and fishery yields of fish from the Gulf of Aden. Journal of Fish Biology 27: 13-21.

11.Von Bertalanffy L (1938) A quantitative theory of organic growth. Human Biology 10: 181-213.

12. Prager MH, Saila SB, Recksiek CW (1989) FISHPARM: a microcomputer program for parameter estimation of nonlinear models in fishery science. Old Dominion University Oceanography Technical Reports 87: 18.

13. Beverton RJH, Holt SJ (1957) on the dynamics of exploited fish populations. Fisheries Investigation. Ministry of Agriculture and Fish Food GB series II, 19: 533.

14. Pauly D (1980) On the interrelationships between natural mortality, growth parameters and mean environmental temperature in 175 fish stocks. ICES Journal of Marine Science 39(2): 175-199.

15. Then AY, Hoenig JM, Hall NG, Hewitt DA (2015) Evaluating the predictive performance of empirical estimators of natural mortality rate using information on over 200 fish species. ICES Journal of Marine Science 72(1): 82-92. 
16. Patterson K (1992) Fisheries for small pelagic species: an empirical approach to management targets. Review of Fish Biology and Fisheries 2: 321-338

17. Pauly D (1984) Fish population dynamics in tropical waters: a manual for use with programmable calculators. ICLARM Review Studies 8 325.

18. Froese R, Binohlan C (2000) Empirical relationships to estimate asymptotic length, length at first maturity and length at maximum yield per recruit in fishes with a simple method to evaluate length frequency data. Journal of Fish Biology 56(4): 758-773.

19. Yamashita H, Katayama S, Komiya T (2015) Age and Growth of Black Sea Bream Acanthopagrus schlegelii (Bleeker, 1854) in Tokyo Bay. Asian Fisheries Science 28: 47-59.

20. James NC, Mann BQ, Beckley LE, Govender A (2003) Age and growth of the estuari ne-dependent sparid Acanthopagrus berda in northern KwaZulu-Natal, South Africa. South African Journal of Zoology 38: 265271.
21. Potter IC, French DJW, Jenkins GI (2008) Comparisons of the growth and gonadal development of otolith-stained, cultured black bream, Acanthopagrus butcheri, in an estuary with those of its wild stock. Reviews in Fisheries Science 16: 303-316.

22. Ochwada-Doyle F, Roberts D, Gray C (2012) Characterizing the biological traits and life history of Acanthopagrus (Sparidae) hybrid complexes: implications for conservation and management. Journal of Fish Biology 81: 1540-1558.

23. El-Ganainy AA (2004) Biological characteristics and fishery assessment of the lizard fish Saurida undosquamis from the Red Sea, Egypt. Egyptian Journal of Aquatic Biology and Fisheries 8: 93-113.

24. Buxton CD, Garratt PA (1990) Alternative reproductive styles in seabreams (Pices: Sparidae). Environmental Biology of Fishes 28: 113124.

\section{Your next submission with Juniper Publishers will reach you the below assets}

- Quality Editorial service

- Swift Peer Review

- Reprints availability

- E-prints Service

- Manuscript Podcast for convenient understanding

- Global attainment for your research

- Manuscript accessibility in different formats

( Pdf, E-pub, Full Text, Audio)

- Unceasing customer service

Track the below URL for one-step submission https://juniperpublishers.com/online-submission.php 